\title{
Hubungan pedagogical content knowledge guru matematika dan prestasi belajar siswa sekolah menengah pertama
}

\author{
Maria Evarista Oktaviane Barut ${ }^{1 *}$, Ariyadi Wijaya 2 (D), Heri Retnawati ${ }^{2}$ \\ ${ }^{1}$ Master Program in Mathematics Education, Universitas Negeri Yogyakarta, Yogyakarta, Indonesia \\ ${ }^{2}$ Department of Mathematics Education, Universitas Negeri Yogyakarta, Yogyakarta, Indonesia \\ * Corresponding Author. E-mail: mariaevarista.2018@student.uny.ac.id
}

\begin{tabular}{ll}
\hline \multicolumn{1}{c}{ ARTICLE INFO } & \multicolumn{1}{c}{ ABSTRACT } \\
\hline Article History: & Guru telah dikenal luas sebagai salah satu faktor penting yang mempengaruhi prestasi belajar \\
Received: 02 Nov. 2020 & siswa. Kompetensi guru, khususnya pengetahuannya, membantu guru untuk mengorganisasi- \\
Revised: 08 Jan. 2021 & kan pembelajaran yang efektif guna memfasilitasi keberhasilan belajar siswa. Salah satu jenis \\
Accepted: 27 Jan. 2021 & pengetahuan yang penting dikuasai oleh guru adalah Pedagogical Content Knowledge (PCK). \\
& PCK merupakan kombinasi pengetahuan konten dan pedagogi yang mengarah pada bagaimana \\
Keywords: & aspek-aspek tertentu dari materi pembelajaran diatur, diadaptasi, dan direpresentasikan untuk \\
Prestasi belajar matema- & diterapkan di dalam proses pembelajaran. Penelitian ini bertujuan untuk mendeskripsikan ting- \\
tika, & kat PCK guru matematika dan prestasi belajar siswa, serta menguji hubungan keduanya. Pene- \\
Learning achievement, & litian ini adalah kuantitatif-korelasional dengan subjek penelitian 56 guru matematika dan 499 \\
Mathematics teacher, & siswa SMP di Kabupaten Manggarai, Nusa Tenggara Timur. Data PCK guru dan prestasi siswa \\
Pedagogical content know- & dikumpulkan menggunakan tes objektif yang telah dinyatakan valid dan reliabel. Data dianalisis \\
ledge. & menggunakan statistik deskriptif dan inferensial. Hasil penelitian mengungkapkan bahwa seba- \\
& gian besar guru memiliki PCK pada kategori rendah dan sebagian besar siswa memiliki prestasi \\
& belajar pada kategori rendah. Namun demikian, terdapat korelasi positif yang signifikan antara \\
& PCK guru matematika dan prestasi belajar siswa dengan kontribusi PCK guru terhadap prestasi \\
& belajar siswa sebesar 16,1\%. \\
\cline { 2 - 3 }
\end{tabular}

Scan me:

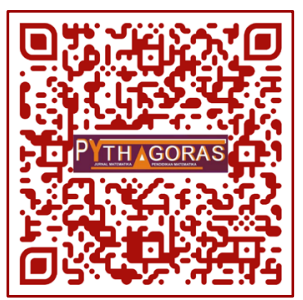

Teachers' competence, especially their knowledge, helps them organize effective classrooms to facilitate students' success. One of the essential knowledge that should be mastered by a teacher is Pedagogical Content Knowledge (PCK). PCK represents the combination of knowledge about content and pedagogy to understand how particular aspects of subject matter are organized, adapted, and represented for instruction. This study aimed to describe mathematics teachers' PCK and students' learning achievement as well as and between the two variables. The study was qualitative-correlational with 56 mathematics teachers and 499 senior high school students in Manggarai Regency, East Nusa Tenggara, Indonesia, as the subject. Both data of teachers' PCK and students' learning achievement were collected using validated and reliable objective tests. Data were analyzed using descriptive and inferential statistics. The results indicated that most teachers have PCK in the low category, and most students have learning achievement in the low category. However, there was a positive correlation between teachers' $P C K$ and students' learning achievement, with the contribution of the teachers' PCK to students' learning achievement by $16.1 \%$.

This is an open access article under the CC-BY-SA license

\section{How to Cite:}

Barut, M. E. O., Wijaya, A., \& Retnawati, H. (2020). Analisis hubungan antara pedagogical content knowledge guru matematika dan prestasi belajar siswa sekolah menengah pertama. Pythagoras: Jurnal Pendidikan Matematika, 15(2), 178-189. https://doi.org/10.21831/pg.v15i2.35375

https://doi.org/10.21831/pg.v15i2.35375

\section{PENDAHULUAN}

Kesuksesan belajar siswa yang dibuktikan melalui pencapaian prestasi belajarnya merupakan salah satu indikator keberhasilan proses pendidikan secara keseluruhan. Prestasi belajar matematika merupakan cerminan kom- 
petensi yang ditunjukkan siswa dalam hal penguasaannya terhadap pengetahuan, pemahaman, keterampilan, dan teknik yang dikembangkan selama pembelajaran matematika pada tingkatan kelas tertentu (Tanujaya et al., 2017). Pencapaian prestasi belajar khususnya dalam pelajaran matematika merupakan bagian penting dari kesuksesan akademis individu yang selanjutnya dapat mendukung keberhasilan profesi di masa depan (Pandey, 2017). Pengukuran terhadap prestasi belajar dapat ditinjau dari proses kognitifnya yang mencakup tiga domain kognitif, yaitu pengetahuan, aplikasi, dan penalaran (Lee \& Huh, 2014; Mullis et al., 2016). Aspek pengetahuan mencakup penguasaan tentang fakta, prosedur, dan konsep. Aspek aplikasi merujuk pada kemampuan siswa untuk menerapkan pengetahuan dan pemahaman konsep untuk menyelesaikan masalah. Adapun aspek penalaran mencakup kemampuan terkait menemukan pola, menggeneralisasi pola, merumuskan dugaan, serta melakukan penarikan simpulan yang logis untuk menyelesaikan masalah matematika (Absorin \& Sugiman, 2018).

Fokus terhadap pencapaian prestasi belajar siswa biasanya diikuti dengan upaya-upaya tertentu untuk mengidentifikasi faktor-faktor yang mempengaruhi prestasi belajar. Salah satu faktor tersebut adalah guru. Guru tidak diragukan lagi merupakan faktor yang memberikan pengaruh besar terhadap peningkatan kualitas pendidikan di berbagai negara (Retnawati et al., 2018). Guru adalah salah satu faktor yang sering ditelaah oleh praktisi sebagai penentu bagi prestasi belajar siswa. Kualitas kompetensi guru merupakan salah satu faktor yang berpengaruh langsung terhadap prestasi belajar siswa (Hakim, 2015; Loughran et al., 2001; Widodo, 2017). Guru merupakan salah satu unsur strategis dalam proses peningkatan mutu pendidikan karena guru memiliki peran untuk memfasilitasi belajar siswa sehingga dapat mencapai kualitas yang diharapkan. Tugas guru adalah menyiapkan individuindividu dalam menguasai pengetahuan dan keterampilan melalui penyelenggaraan aktivitas pembelajaran di kelas. Di sisi lain, proses pembelajaran merupakan sebuah aktivitas kompleks, sehingga untuk merencanakan dan menjalankan pembelajaran efektif bukan suatu hal yang mudah dilakukan. Beberapa studi terdahulu telah membuktikan bahwa penyelenggaraan pembelajaran yang efektif membutuhkan keluasan dan kekayaan pengetahuan yang dimiliki oleh guru (Ekawati et al., 2015; Wilson et al., 2002).

Pengetahuan guru dipandang sebagai komponen utama dari kompetensi profesional guru. Hal ini cukup beralasan karena apa yang diketahui guru memengaruhi cara memfasilitasi belajar siswa dan apa yang dipelajari siswa (Gess-Newsome, 2015). Pengetahuan profesional guru diyakini menjadi sumber penting dalam memfasilitasi penyediaan berbagai kesempatan belajar yang menantang dan memotivasi bagi siswa (Baumert et al., 2010). Menurut National Council of Teachers of Mathematics (NCTM) agar dapat memfasilitasi pembelajaran yang efektif, guru harus mengetahui dan memahami secara mendalam materi matematika yang akan diajarkan dan dapat menyampaikan pengetahuan tersebut secara fleksibel dalam tugas mengajar mereka (NCTM, 2000). Dengan kata lain, pengetahuan yang penting untuk dikuasai guru mencakup penguasaan terhadap materi pelajaran (content knowledge) itu sendiri dan pengetahuan pedagogis (pedagogical knowledge) (Aminah \& Wahyuni, 2018; Anthony \& Walshaw, 2009; Brahier, 2016). Content knowledge atau pengetahuan konten mencakup penguasaan terhadap fakta, konsep, prosedur, dan aturan matematika. Adapun pedagogical knowledge atau pengetahuan pedagogis mencakup penguasaan terhadap prinsip-prinsip pembelajaran, teknik-teknik pembelajaran, pengelolaan kelas, hingga manajemen siswa dalam pembelajaran.

Guru, pada praktiknya, tidak hanya mengandalkan content knowledge saja atau pedagogical knowledge saja dalam menjalankan tugas untuk memfasilitasi siswa belajar. Penting bagi guru untuk menguasai pengetahuan yang mengombinasikan kedua jenis pengetahuan tersebut untuk selanjutnya digunakan secara simultan dalam menciptakan pembelajaran efektif yang dapat menjamin tercapainya keberhasilan siswa dalam belajar. Integrasi kedua jenis pengetahuan ini disebut sebagai pedagogical content knowledge. Pedagogical content knowledge ini dianggap sebagai persyaratan minimal yang terlebih dahulu harus dikuasai oleh guru untuk menjadi guru yang kompeten (Rafi \& Sugiman, 2019). Istilah pedagogical content knowledge, yang selanjutnya disingkat menjadi PCK, pertama kali diperkenalkan oleh Lee Shulman pada tahun 1986. Shulman (1987) menyebut PCK sebagai pengetahuan yang mewakili kombinasi antara content knowledge dan pedagogical knowledge menjadi pemahaman tentang bagaimana aspek-aspek tertentu dari materi pembelajaran diatur, diadaptasi, dan direpresentasikan untuk menciptakan proses pembelajaran yang baik. Sedangkan menurut Ball dan Bass (2000), PCK adalah bentuk pengetahuan khusus yang menggabungkan pengetahuan matematika dengan pengetahuan peserta didik, pembelajaran, dan pedagogi yang menjadi modal dalam membelajarkan matematika karena dapat membantu guru dalam mengantisipasi apa yang mungkin sulit dipelajari oleh siswa dan mengatasi kesulitan tersebut.

Konseptualisasi awal yang dikemukakan oleh Shulman membagi PCK atas dua komponen utama yaitu pengetahuan tentang representasi matematika (knowledge of representation) dan pengetahuan tentang pemahaman 
terhadap siswa (knowledge of student) (Evens et al., 2015; Shulman, 1987). Namun dalam beberapa dekade terakhir, konseptualisasi ini telah banyak dikembangkan oleh para praktisi sehingga terdapat penambahan beberapa komponen dari PCK yang di antaranya adalah pengetahuan tentang kurikulum dalam pembelajaran matematika (knowledge of curriculum) dan pengetahuan tentang penilaian dalam pembelajaran matematika (knowledge of assessment). Pengetahuan tentang representasi adalah pengetahuan guru tentang ilustrasi strategi, analogi, penjelasan, dan demonstrasi yang digunakan untuk membuat materi pelajaran dapat dipahami oleh siswanya (Hume \& Berry, 2011). Pengetahuan tentang pemahaman terhadap siswa adalah pengetahuan yang dimiliki guru terkait, konsepsi, miskonsepsi, dan kesulitan yang biasa dialami siswa pada ide matematika tertentu (Ball et al., 2008). Pengetahuan terhadap kurikulum menyangkut pengetahuan guru tentang sasaran dan tujuan kurikulum sekaligus muatan pembelajaran sesuai dengan kurikulum yang ada untuk diajarkan pada tingkatan kelas tertentu (Appova \& Taylor, 2019). Adapun pengetahuan asesmen mencakup pengetahuan tentang ide-ide matematika yang penting untuk dinilai dalam pembelajaran matematika (Lannin et al., 2013).

Komponen-komponen dari PCK yang telah disebutkan menunjukkan salah satu konstruk yang lengkap sehingga dapat membantu guru dalam menyusun konten pembelajaran, memilih atau mengembangkan representasi atau analogi tertentu, dan memahami dan mengantisipasi miskonsepsi tertentu atau kesulitan belajar yang dialami siswa. Seperti yang dikemukakan Kleickmann et al. (2013) dan Park dan Oliver (2008) bahwa PCK merupakan pengetahuan guru untuk mentransformasi materi pembelajaran ke dalam bentuk yang mudah dimengerti oleh siswa dengan berlandaskan pada pemahaman mendalam tentang konsepsi dan miskonsepsi siswa pada materi tertentu, serta pengetahuan tentang strategi pengajaran dan representasi yang tepat untuk mengajarkan suatu materi tertentu. Penguasaan PCK berguna sebagai penuntun untuk guru dalam menghadapi dan mengatasi kesulitan mengajar di kelas, serta memperbaiki dan mengevaluasi praktik pembelajaran mereka (Bucat, 2004). Berdasarkan pendapat para ahli tersebut, dapat disimpulkan penguasaan guru terhadap PCK merupakan bekal untuk penyelenggaraan pembelajaran efektif yang selanjutnya berpengaruh terhadap pencapaian prestasi belajar siswa.

Penelitian terdahulu terkait PCK telah dilakukan oleh beberapa ahli. Olfos et al. (2014) telah meneliti hubungan antara PCK guru dengan prestasi belajar siswa kelas empat sekolah dasar di Chili. Selanjutnya, Maryani dan Martaningsih (2015) juga telah melakukan penelitian untuk menyelidiki hubungan antara PCK guru dengan motivasi belajar siswa. Penelitian lainnya dilakukan oleh Dirgahayu (2020) yang menyelidiki hubungan antara PCK guru dengan kinerja guru matematika. Dari beberapa studi yang telah dipaparkan tersebut, belum ada yang mengkaji hubungan antara pengetahuan guru dan pencapaian belajar siswa terkhusus di tingkat Sekolah Menengah Pertama (SMP). Beberapa ahli juga mengakui bahwa penelitian tentang pengetahuan guru belum banyak dilakukan di Indonesia (Ng, 2012) termasuk di antaranya penelitian tentang PCK (Sarkim, 2015). Begitu pula penelitian yang menyelidiki hubungan antara pengetahuan guru dan pencapaian belajar masih belum banyak dilakukan (Telese, 2012). Sejalan dengan ini, Alonzo et al. (2012) juga menyatakan bahwa baru terdapat sedikit bukti langsung terkait hubungan antara PCK guru dan hasil belajar siswa. Berdasarkan pemaparan tersebut penelitian ini difokuskan untuk menyelidiki dan mendeskripsikan hubungan antara prestasi belajar matematika siswa Sekolah Menengah Pertama (SMP) dan PCK guru matematika SMP. Selain itu, penelitian ini juga menggali pemahaman terhadap tingkat pencapaian prestasi belajar matematika siswa dan tingkat PCK guru matematika.

\section{METODE}

Penelitian ini merupakan bagian dari penelitian kuantitatif-korelasional yang bertujuan untuk menjelaskan hubungan prestasi belajar siswa dan PCK guru matematika. Subjek dalam penelitian ini adalah 56 guru matematika dan 499 siswa yang berasal dari 17 Sekolah Menengah Pertama (SMP) dari 71 SMP yang ada di Kabupaten Manggarai, Nusa Tenggara Timur (NTT). Tujuh belas SMP tersebut dibedakan menjadi tiga level; yaitu level tinggi, sedang, dan rendah; berdasarkan capaian rata-rata nilai matematika sekolah pada Ujian Nasional (UN) tahun 2019 dan kriteria yang ditetapkan oleh Ebel dan Frisbie (1991). Berdasarkan hal tersebut, 17 SMP yang dimaksud terdiri atas enam sekolah level tinggi $(\bar{x} \geq 57,09)$, enam sekolah level sedang $(47,99 \leq \bar{x}<57,09)$, dan lima sekolah level rendah $(\bar{x}<47,99)$. Detail karakteristik guru dan siswa yang terlibat dalam penelitian ini disajikan dalam Tabel 1. Karena adanya keterbatasan penelitian, hanya ada 32 kelompok kelas siswa yang akan dianalisis secara inferensial. Selanjutnya kelompok-kelompok kelas ini akan dipasangkan dengan 32 guru matematika untuk dilakukan analisis hubungan antara kedua variabel (PCK guru dan prestasi belajar siswa). 
Tabel 1. Karakteristik subjek penelitian

\begin{tabular}{llr}
\hline Deskripsi & & Jumlah $(\%)$ \\
\hline Sekolah & Swasta & $4(7,41)$ \\
\multirow{3}{*}{ Guru } & Negeri & $13(92,59)$ \\
& Swasta & $11(19,64)$ \\
\multirow{2}{*}{ Pengalaman mengajar guru } & Negeri & $45(80,36)$ \\
& $\leq 5$ tahun & $23(41,07)$ \\
Status sertifikasi guru & $>5$ tahun & $33(58,93)$ \\
& Sudah & $30(53,57)$ \\
Siswa & Belum & $26(46,43)$ \\
& Kelas 7 & $239(47,90)$ \\
& Kelas 8 & $260(52,10)$ \\
\hline
\end{tabular}

\section{Instrumen Penelitian}

Instrumen yang digunakan untuk berupa tes PCK guru dan tes prestasi belajar siswa. Tes PCK guru terdiri atas 10 soal pilihan ganda dan 10 soal uraian yang mencakup lima soal untuk menilai pengetahuan tentang representasi matematika, lima soal untuk menilai pengetahuan tentang pemahaman siswa, lima soal untuk menilai pengetahuan tentang kurikulum, dan lima soal untuk menilai pengetahuan tentang penilaian dalam pembelajaran matematika. Adapun indikator soal pada tes PCK disajikan dalam Tabel 2.

Tabel 2. Indikator soal tes PCK guru

\begin{tabular}{|c|c|}
\hline Aspek & Indikator \\
\hline $\begin{array}{l}\text { Pengetahuan terhadap } \\
\text { representasi suatu } \\
\text { topik matematika } \\
\text { tertentu }\end{array}$ & $\begin{array}{l}\text { Memilih representasi (aktivitas, representasi, dan pertanyaan) yang efektif dalam } \\
\text { mengajarkan materi } \\
\text { Memilih strategi (aktivitas, representasi, dan pertanyaan) untuk memperbaiki } \\
\text { miskonsepsi/kesulitan siswa } \\
\text { Mengidentifikasi kelemahan dan kelebihan dalam menggunakan representasi } \\
\text { tertentu pada pengajaran materi } \\
\text { Mengidentifikasi materi prasyarat untuk mengajarkan materi matematika }\end{array}$ \\
\hline $\begin{array}{l}\text { Pengetahuan terhadap } \\
\text { pemahaman siswa } \\
\text { pada suatu topik } \\
\text { matematika tertentu }\end{array}$ & $\begin{array}{l}\text { Menuliskan tipikal respons/jawaban siswa dalam menyelesaikan masalah } \\
\text { matematika } \\
\text { Mengidentifikasi kesulitan atau kesalahan siswa dalam materi tertentu } \\
\text { Menginterpretasikan cara berpikir siswa melalui jawaban atas soal yang diberikan } \\
\text { Mengantisipasi level kesulitan soal }\end{array}$ \\
\hline $\begin{array}{l}\text { Pengetahuan tentang } \\
\text { kurikulum }\end{array}$ & $\begin{array}{l}\text { Mengidentifikasi indikator pencapaian kompetensi (IPK) yang sesuai untuk suatu } \\
\text { kompetensi dasar tertentu } \\
\text { Menganalisis ketepatan rumusan suatu Indikator Pencapaian Kompetensi dari } \\
\text { Kompetensi Dasar } \\
\text { Menentukan pengalaman belajar yang sesuai untuk tujuan pembelajaran tertentu } \\
\text { Mengorganisasikan urutan mengajar materi dalam satu pokok bahasan tertentu }\end{array}$ \\
\hline $\begin{array}{l}\text { Pengetahuan terhadap } \\
\text { penilaian/asesmen }\end{array}$ & $\begin{array}{l}\text { Mengidentifikasi ide/konsep yang sesuai untuk dinilai. } \\
\text { Memilih jenis soal yang tepat untuk mengukur suatu IPK tertentu } \\
\text { Menentukan jenis soal yang sesuai untuk mengukur tingkat pengetahuan siswa } \\
\text { Menggunakan/memilih metode yang tepat untuk mengukur suatu indikator tertentu }\end{array}$ \\
\hline
\end{tabular}

Adapun tes prestasi belajar siswa terdiri atas 20 soal pilihan ganda yang menguji tingkat pemahaman, aplikasi, dan penalaran. Masing-masing siswa kelas 7 dan kelas 8 diujikan soal prestasi belajar untuk kompetensi dasar yang berbeda-beda seperti yang ditunjukkan dalam Tabel 3. Tes prestasi belajar untuk siswa kelas 7 mencakup enam soal untuk aspek pemahaman, sembilan soal untuk aspek aplikasi, dan lima soal untuk aspek penalaran. Sementara untuk kelas 8 terdiri atas 10 soal untuk aspek pemahaman, enam soal untuk aspek aplikasi, dan empat soal untuk aspek penalaran. 
Tabel 3. Kompetensi dasar tes prestasi belajar siswa kelas 7 dan kelas 8

\begin{tabular}{ll}
\hline Kompetensi dasar tes prestasi kelas 7 & Kompetensi dasar tes prestasi kelas 8 \\
\hline $\begin{array}{l}\text { Menjelaskan dan melakukan operasi hitung bilangan } \\
\text { bulat dan pecahan dengan memanfaatkan berbagai }\end{array}$ & $\begin{array}{l}\text { Menganalisis fungsi linear (sebagai persamaan garis } \\
\text { sifat operasi }\end{array}$ \\
$\begin{array}{ll}\text { Menyelesaikan masalah yang berkaitan dengan menginterpretasikan grafiknya yang } \\
\text { operasi hitung bilangan bulat dan pecahan }\end{array}$ & $\begin{array}{c}\text { Menyelesaikan masalah kontekstual yang berkaitan } \\
\text { dengan fungsi linear sebagai persamaan garis lurus }\end{array}$ \\
\hline
\end{tabular}

Validitas dan Reliabilitas Instrumen

Tes PCK guru dan tes prestasi belajar yang digunakan dalam penelitian ini telah dinyatakan dan dibuktikan valid berdasarkan penilaian oleh dua ahli yang merupakan dosen bergelar Doktor di Program Studi S2 Pendidikan Matematika, Universitas Negeri Yogyakarta. Sedangkan untuk estimasi koefisien reliabilitas menggunakan formula Alpha Cronbach. Koefisien reliabilitas untuk tes PCK guru pilihan ganda, tes PCK guru uraian, tes prestasi belajar kelas 7 , tes prestasi belajar kelas 8 berturut-turut adalah 0,643; 0,785; 0,644; dan 0,634 yang mana semuanya memenuhi kriteria reliabel (Ebel \& Frisbie, 1991; Hair et al., 2018).

\section{Teknik Analisis Data}

Analisis data menggunakan analisis statistik deskriptif dan analisis statistik inferensial. Analisis secara deskriptif dilakukan dengan menghitung skor total dari hasil jawaban guru dan siswa. Berdasarkan skor total ini kemudian dicari skor maksimum, skor minimum, rata-rata skor, dan standar deviasi untuk masing-masing data siswa kelas 7 , data siswa kelas 8, dan data PCK guru matematika. Selain itu, skor total masing-masing subjek dicocokkan dengan Kualifikasi Prestasi Belajar Siswa dan Tingkat PCK guru. Mengacu pada kategorisasi kompetensi lulusan pada Ujian Nasional (Badan Standar Pendidikan Nasional, 2018), maka kualifikasi pencapaian belajar siswa terbagi atas empat kategori sebagaimana tersaji dalam Tabel 4.

Tabel 4. Kriteria kategori prestasi belajar siswa

\begin{tabular}{ll}
\hline Interval skor & Kategori \\
\hline $86-100$ & Sangat tinggi \\
$71-85$ & Tinggi \\
$56-70$ & Cukup \\
$00-55$ & Rendah \\
\hline
\end{tabular}

Kriteria PCK guru yang digunakan dalam penelitian ini mengacu pada kualifikasi penilaian kinerja guru pada Peraturan Menteri Negara Pendayagunaan Aparatur Negara dan Reformasi Birokrasi Nomor 16 Tahun 2009 tentang Jabatan Fungsional Guru dan Angka Kreditnya (Wea, 2012). Berdasarkan kualifikasi tersebut, tingkat PCK guru dibedakan menjadi lima kategori sebagaimana tersaji dalam Tabel 5.

Tabel 5. Kriteria kategori PCK guru

\begin{tabular}{ll}
\hline Interval skor & Kategori \\
\hline $85<x<100$ & Sangat baik \\
$70<x \leq 85$ & Baik \\
$50<x \leq 70$ & Cukup \\
$25<x \leq 50$ & Kurang \\
$x \leq 25$ & Sangat kurang \\
\hline
\end{tabular}

Analisis statistik inferensial dilakukan untuk memeriksa hubungan antara tingkat PCK guru dengan prestasi belajar matematika siswa. Analisis ini menggunakan uji korelasi pada 32 pasangan data skor PCK guru dan data skor prestasi belajar siswa. Uji korelasi yang digunakan adalah korelasi product moment pada taraf signifikansi 5\%. Untuk itu, rata-rata skor prestasi belajar dari masing-masing kelas dihitung dan dipasangkan dengan skor PCK guru yang mengampu pelajaran matematika di kelas tersebut. Hipotesis yang akan diuji pada penelitian ini adalah terdapat korelasi antara PCK guru dan prestasi belajar siswa. Adapun kriteria keputusan yaitu hipotesis alternatif 
diterima jika nilai indeks korelasi $\left(r_{x y}\right)$ lebih besar dari nilai $r_{\text {tabel }}$ atau nilai signifikansi $p<0,05$. Nilai indeks korelasi juga akan digunakan untuk mendeskripsikan tingkat kekuatan hubungan antara PCK guru dan prestasi belajar matematika siswa. Interpretasi nilai indeks korelasi dapat dilihat pada Tabel 6 . Selanjutnya juga akan ditentukan koefisien determinasi yang berguna untuk mengetahui besarnya kontribusi PCK guru terhadap prestasi belajar matematika siswa. Selain itu, analisis regresi juga digunakan untuk menemukan model yang menyatakan hubungan antara variabel bebas PCK guru $(X)$ dan variabel terikat prestasi belajar matematika siswa $(Y)$.

Tabel 6. Interpretasi koefisien korelasi produk momen

\begin{tabular}{ll}
\hline Nilai indeks korelasi & Interpretasi \\
\hline $0,00-0,19$ & $\begin{array}{c}\text { Antara kedua variabel terdapat korelasi namun sangat lemah sehingga dapat dianggap } \\
\text { tidak ada korelasi antara kedua variabel }\end{array}$ \\
$0,20-0,34$ & Antara kedua variabel terdapat korelasi yang lemah \\
$0,35-0,64$ & Antara kedua variabel terdapat korelasi yang sedang atau cukup \\
$0,65-0,84$ & Antara kedua variabel terdapat korelasi yang kuat atau tinggi \\
$0,85-1,00$ & Antara kedua variabel terdapat korelasi yang sangat kuat atau sangat tinggi \\
\hline
\end{tabular}

Sumber: Lodico et al. ( 2010)

\section{HASIL PENELITIAN}

\section{Prestasi Belajar Siswa}

Analisis hasil tes prestasi belajar matematika siswa dilakukan dengan menghitung skor total untuk masingmasing siswa. Berdasarkan skor total tersebut, statistik deskriptif data prestasi belajar matematika siswa disajikan dalam Tabel 7.

Tabel 7. Statistik deskriptif data prestasi belajar siswa

\begin{tabular}{lccccc}
\hline Deskripsi & Banyak siswa $(n)$ & Skor minimum & Skor maksimum & Rata-rata & Standar deviasi \\
\hline Kelas 7 & 239 & 0 & 90 & 32,22 & 15,80 \\
$\quad$ Pemahaman & & 0 & 83,33 & 38,15 & 21,09 \\
Aplikasi & & 0 & 100 & 29,57 & 19,56 \\
$\quad$ Penalaran & & 0 & 80 & 29,87 & 21,84 \\
Kelas 8 & 260 & 0 & 75 & 28,01 & 10,42 \\
Pemahaman & & 0 & 77,78 & 29,19 & 16,03 \\
Aplikasi & & 0 & 85,71 & 23,27 & 15,49 \\
Penalaran & & 0 & 100 & 23,17 & 20,70 \\
\hline
\end{tabular}

Analisis lebih lanjut terhadap data prestasi belajar matematika siswa dilakukan dengan mencocokkan skor masing-masing siswa dengan kualifikasi pencapaian prestasi belajar. Kemudian dihitung persentase total siswa untuk masing-masing kategori sehingga diperoleh sebaran pencapaian prestasi belajar siswa untuk masing-masing kelas 7 dan kelas 8 sebagaimana yang disajikan dalam Tabel 8 .

Tabel 8. Distribusi prestasi belajar siswa di Kabupaten Manggarai

\begin{tabular}{lrrrr}
\hline \multirow{2}{*}{ Kategori } & \multicolumn{2}{c}{ Kelas 7 } & \multicolumn{2}{c}{ Kelas 8 } \\
\cline { 2 - 5 } & $n$ & $\%$ & $n$ & $\%$ \\
\hline Sangat tinggi & 2 & 0,8 & 0 & 0 \\
Tinggi & 2 & 0,8 & 0 & 0 \\
Cukup & 19 & 7,9 & 1 & 0,4 \\
Rendah & 216 & 90,4 & 259 & 99,6
\end{tabular}

Tabel 7 menunjukkan bahwa pencapaian rata-rata prestasi belajar siswa untuk masing-masing kelas di termasuk dalam kategori rendah. Selain itu, skor siswa kelas 7 berada pada rentang 0 sampai dengan 90 sementara skor siswa kelas 8 berada pada rentang 0 sampai 75 . Baik kelas 7 maupun kelas 8 sebagian besar siswanya berada dalam kategori rendah untuk pencapaian prestasi belajar siswa dengan hanya sedikit siswa memperoleh prestasi belajar yang tinggi (lihat Tabel 8). 
Analisis lebih lanjut dilakukan terhadap masing-masing aspek tes prestasi belajar siswa, yakni mencakup aspek pemahaman, aplikasi, dan penalaran seperti yang disajikan dalam Tabel 7. Rerata skor untuk semua aspek prestasi belajar untuk kedua kelas termasuk dalam kategori rendah. Pada siswa kelas 7 aspek pemahaman lebih mampu dikuasai dibandingkan dengan dua aspek lainnya. Sedangkan pada kelas 8 penguasaan pada aspek pemahaman dan aplikasi lebih baik dibandingkan penguasaan penalaran.

\section{Pedagogical Content Knowledge (PCK) Guru Matematika}

Analisis terhadap PCK guru diawali dengan perhitungan terhadap statistik deskriptif dari skor-skor PCK guru. Hasil perhitungan tersebut ditunjukkan dalam Tabel 9 . Analisis lanjutan juga dilakukan berdasarkan akumulasi skor pada keempat aspek yaitu pengetahuan terhadap pemahaman siswa pada materi pembelajaran tertentu, pengetahuan terhadap representasi suatu topik matematika, pengetahuan terhadap kurikulum, dan pengetahuan terhadap penilaian/asesmen, di mana hasil analisis ini disajikan dalam Tabel 9. Rata-rata skor PCK untuk semua aspek tersebut termasuk dalam kategori rendah. Selain itu, rata-rata-tersebut menunjukkan bahwa guru lebih menguasai pengetahuan tentang asesmen/penilaian dibandingkan jenis pengetahuan lainnya. Aspek PCK yang kurang dikuasai oleh guru adalah apek pengetahuan terhadap kurikulum. Lebih lanjut, secara keseluruhan skor PCK guru berada pada rentang 17,5 sampai 73,06 dengan rata -rata yang juga tergolong rendah yakni 44,52.

Tabel 9. Statistik deskriptif PCK guru matematika

\begin{tabular}{lccccc}
\hline Deskripsi & Banyak guru $(n)$ & Skor minimum & Skor maksimum & Rata-rata & Standar deviasi \\
\hline PCK guru & 56 & 17,5 & 73,06 & 44,52 & 14,22 \\
Representasi & & 11,76 & 94,12 & 52,31 & 22,05 \\
Pemahaman siswa & & 11,76 & 76,47 & 41,39 & 14,97 \\
Kurikulum & & 0 & 60 & 30,18 & 19,95 \\
Asesmen & & 28,57 & 100 & 64,94 & 19,98 \\
\hline
\end{tabular}

Selanjutnya dihitung persentase total guru untuk tiap kategori pencapaian PCK (lihat Tabel 10). Berdasarkan Tabel 10 dapat disimpulkan secara keseluruhan pencapaian PCK guru matematika di Kabupaten Manggarai masih rendah. Hanya sebagian kecil guru yang memiliki kategori yang tinggi (baik).

Tabel 10. Distribusi PCK guru matematika

\begin{tabular}{lrr}
\hline Kategori & $n$ & $\%$ \\
\hline Sangat baik & 0 & 0 \\
Baik & 2 & 3,6 \\
Cukup & 18 & 32,1 \\
Kurang & 33 & 58,9 \\
Sangat kurang & 3 & 5,4 \\
\hline
\end{tabular}

\section{Hubungan antara Pedagogical Content Knowledge (PCK) Guru dan Prestasi Belajar Siswa}

Untuk menguji hubungan antara PCK guru dan prestasi belajar siswa digunakan pasangan skor prestasi belajar siswa (rata-rata skor kelas) beserta skor PCK guru yang mengampu pelajaran matematika di kelas tersebut. Analisis hubungan antara PCK guru dengan prestasi belajar siswa dilakukan dengan uji korelasi produk momen. Namun sebelum itu, dilakukan uji prasyarat berupa uji normalitas dan uji linearitas (Cohen et al., 2007; Gunur et al., 2019). Uji normalitas digunakan untuk mengidentifikasi normal atau tidaknya distribusi data yang ada. Hasil uji normalitas Kolmogorov-Smirnov mengindikasikan bahwa skor PCK guru mengikuti distribusi normal $(D(32)=0,149, p=0,068)$. Begitu pula untuk skor prestasi belajar siswa mengikuti distribusi normal $(D(32)=0,141, p=0,104)$. Selanjutnya, uji linearitas digunakan untuk mengetahui ada atau tidaknya hubungan linear antara variabel terikat (prestasi belajar siswa SMP) dan variabel bebas (PCK guru). Hasil analisis menunjukkan nilai signifikansi deviation from linearity sebesar 0,143 $(p>0,05)$. Dengan demikian, dapat disimpulkan bahwa terdapat hubungan linear antara PCK guru dan prestasi belajar siswa.

Setelah normalitas dan linearitas data telah terpenuhi maka selanjutnya dapat dilakukan analisis melalui uji korelasi product moment. Hasil analisis mengungkapkan bahwa terdapat korelasi positif yang signifikan antara PCK guru dan prestasi belajar siswa: $r=0,402 ; N=32 ; p=0,023 ; R^{2}=0,161$. Berdasarkan Tabel 6 , koefisien korelasi 
sebesar 0,402 tersebut menunjukkan bahwa derajat hubungan antara PCK guru dan prestasi belajar matematika siswa berada pada kategori sedang atau cukup. Besarnya koefisien determinasi $\left(R^{2}\right)$ sebesar 0,161 mengindikasikan bahwa kontribusi PCK guru terhadap prestasi belajar matematika siswa sebesar $16,1 \%$, sedangkan sisanya sebesar $83,9 \%$ dipengaruhi oleh faktor lain.

\section{PEMBAHASAN}

Analisis data prestasi belajar siswa menunjukkan bahwa sebagian besar siswa memiliki pencapaian prestasi belajar yang rendah. Hal ini berdasarkan sebaran data pencapaian prestasi belajar siswa yang mana menunjukkan bahwa sebagian besar siswa berada pada kategori kurang. Hal ini diperkuat juga dengan rata-rata skor keseluruhan yang mana juga termasuk dalam untuk kategori kurang. Temuan ini sejalan hasil UN dan hasil penilaian Trends in International Mathematics and Science Study (TIMSS). Hasil UN matematika siswa di Kabupaten Manggarai tahun 2019 menunjukkan bahwa 63,73\% siswa memperoleh skor pada kategori kurang. Selain itu, temuan pada studi internasional TIMSS pada tahun 2011 juga menunjukkan bahwa siswa Indonesia berada pada level rendah untuk kemampuan matematika (Mullis et al., 2012; Rosnawati, 2013). Hasil pencapaian TIMSS pada tahun 2015 juga belum menunjukkan perbedaan signifikan, di mana skor matematika siswa Indonesia berada pada urutan 44 dari 49 negara (Mullis et al., 2016).

Studi TIMSS juga mengukur kemampuan matematis siswa Indonesia pada aspek-aspek serupa yang diujikan pada penelitian ini, yaitu pengetahuan, penerapan, dan penalaran. Rata-rata persentase pencapaian siswa pada penilaian TIMSS untuk masing-masing aspek berturut-turut adalah 37\%, 23\%, dan $17 \%$, yang mana selanjutnya mengindikasikan bahwa siswa Indonesia berada pada domain kognitif pemahaman dan aplikasi (Hadi et al., 2018). Capaian rata-rata ini sedikit berbeda dengan rata-rata capaian pada penelitian ini, yang mana pada rata-rata skor tertinggi dihasilkan oleh aspek pemahaman pada kelas 7 yakni sebesar 38,15. Adapun skor rata-rata terendah terletak pada aspek penalaran untuk kelas 8 yaitu sebesar 23,17. Terlepas dari perbedaan ini, semua rata-rata skor sama-sama berada pada kategori rendah. Hasil penelitian ini berbeda dengan penelitian dari Prasetyo dan Rudhito (2016) yang mengujikan soal model TIMSS pada 31 siswa SMP di sekolah di Jawa Tengah, di mana hasil penelitian menunjukkan bahwa capaian skor untuk ketiga aspek termasuk dalam kategori sedang. Perbedaan hasil di antara ketiga penelitian ini mungkin disebabkan oleh beberapa hal yaitu, karakteristik siswa dan juga cakupan materi yang diujikan. Pada penelitian yang dilakukan oleh Prasetyo dan Rudhito (2016), subjek penelitian adalah siswa di Yogyakarta yang mana Yogyakarta sendiri merupakan daerah dengan pencapaian prestasi belajar siswanya di atas ratarata, sementara subjek dalam penelitian ini berasal dari daerah dengan prestasi belajar rendah. Cakupan materi yang diujikan juga berbeda dimana untuk Studi TIMSS menguji pada materi bilangan, aljabar, geometri, serta data dan peluang. Sementara penelitian ini hanya berfokus untuk menguji prestasi belajar siswa pada topik bilangan dan persamaan garis lurus.

Sementara itu, analisis terhadap PCK guru menunjukkan bahwa sebagian besar guru matematika memiliki tingkat PCK yang rendah. Rata-rata skor pada keempat aspek juga berada pada kategori rendah dengan rata-rata terendah dicapai pada aspek pengetahuan terhadap kurikulum. Rendahnya pencapaian pada aspek ini secara tidak langsung mengindikasikan bahwa guru masih kesulitan dalam mengidentifikasi indikator pencapaian kompetensi yang sesuai untuk suatu kompetensi dasar tertentu, menganalisis ketepatan rumusan suatu indikator pencapaian kompetensi dari Kompetensi Dasar (KD), dan mengorganisasikan urutan mengajar materi dalam satu pokok bahasan tertentu. Padahal dengan dikuasainya pengetahuan ini akan membantu guru untuk mengidentifikasi konsep inti dalam matematika, memodifikasi aktivitas dalam pembelajaran, dan menyeleksi aspek-aspek yang tidak sesuai untuk diajarkan pada pemahaman konseptual yang ditargetkan (Park \& Oliver, 2008).

Berdasarkan analisis uji korelasi, terdapat korelasi positif signifikan antara PCK guru matematika dan prestasi belajar matematika siswa. Ini berarti, jika semakin tinggi tingkat PCK guru matematika, maka prestasi belajar matematika siswa juga akan semakin tinggi. Sebaliknya, jika semakin rendah tingkat PCK guru matematika, maka prestasi belajar matematika siswa juga akan semakin rendah. Temuan ini sejalan dengan hasil penelitian dari Campbell et al. (2014) dan Olfos et al. (2014) yang menunjukkan terdapat hubungan signifikan antara tingkat PCK guru dan prestasi belajar siswa. Bahkan penelitian yang dilakukan oleh Baumert et al. (2010) menunjukkan hasil bahwa PCK menjadi prediktor paling kuat bagi prestasi belajar siswa jika dibandingkan dengan content knowledge, di mana PCK menjelaskan $39 \%$ variansi pada prestasi belajar siswa.

Adanya hubungan dan kontribusi PCK guru terhadap prestasi belajar siswa membuktikan bahwa PCK sebagai pengetahuan yang penting dimiliki guru dalam menjalankan tugasnya sebagai pendidik. PCK merupakan pengeta- 
huan pokok yang menjadi penuntun bagi guru dalam mengambil keputusan ataupun mengambil tindakan dalam proses pembelajaran di kelas (Atay et al., 2010). PCK membantu guru mengenali karakteristik siswa termasuk kesulitan, miskonsepsi, dan persepsi siswa pada materi tertentu yang kemudian dapat digunakan sebagai bahan pertimbangan untuk memilih representasi atau model pembelajaran yang sesuai dengan karakteristik siswa sehingga nantinya akan membantu guru dalam proses memfasilitasi siswa membangun pengetahuannya. PCK juga mencakup pengetahuan terkait mengantisipasi, menafsirkan, menilai, dan menanggapi cara siswa berpikir (Goos, 2013), sehingga pemahaman ini membantu guru untuk menyiapkan pembelajaran yang dapat memfasilitasi keberhasilan siswa (Barut \& Wijaya, 2020). Sehingga tanpa penguasaan PCK yang mumpuni guru akan kesulitan untuk menyelenggarakan pembelajaran secara efektif. Tanpa penyelenggaraan pembelajaran yang efektif akan menghambat proses belajar siswa untuk mendapatkan pengetahuan dan keterampilan sehingga menyebabkan kegagalan siswa dalam pembelajaran.

Nilai indeks korelasi sebesar 0,402 mengindikasikan tingkat kekuatan korelasi antara PCK guru dan prestasi belajar matematika siswa berada pada level sedang. Meskipun indeks korelasi hanya berada pada kategori sedang, namun temuan ini mengindikasikan bahwa PCK guru matematika memiliki kontribusi yang cukup untuk mempengaruhi prestasi belajar siswa. Sedangkan nilai koefisien determinasi menunjukkan besarnya kontribusi PCK guru terhadap prestasi belajar matematika siswa hanya sebesar $16,1 \%$, sedangkan $83,9 \%$ ditentukan oleh faktor lain. Berdasarkan hasil ini dapat disimpulkan bahwa PCK bukan satu-satunya faktor yang mempengaruhi pencapaian belajar siswa. Beberapa penelitian mengungkapkan bahwa prestasi belajar siswa dapat dipengaruhi oleh faktorfaktor terkait karakteristik individual seperti minat siswa dalam belajar serta konsep diri (Uysal, 2015) atau faktor terkait sekolah misalnya tingkat kedisiplinan di lingkungan sekolah (Shin et al., 2009).

Terdapat beberapa keterbatasan dalam penelitian ini. Pertama, identifikasi hubungan PCK guru dan prestasi belajar matematika harusnya menggunakan 34 pasangan skor. Namun dalam penelitian ini hanya menggunakan 32 pasang skor karena terdapat 2 kelompok kelas siswa yang tidak memenuhi syarat. Hal ini dikarenakan terdapat skor prestasi belajar yang tidak mempunyai pasangan skor PCK guru, karena terdapat guru matematika yang mengampu pelajaran matematika pada kelas tersebut tidak bersedia untuk terlibat dalam penelitian. Selain itu, terdapat kelompok kelas siswa dengan jumlah partisipan yang sedikit ( $<10$ siswa). Sehingga rata-rata skor prestasi dari kelas ini tidak diambil karena dikhawatirkan kurang representatif. Keterbatasan lainnya terkait dengan bias terhadap hasil penelitian. Penelitian ini hanya berfokus pada PCK guru sebagai faktor yang mempengaruhi pencapaian prestasi belajar siswa. Padahal masih banyak faktor lainnya yang dapat mempengaruhi prestasi belajar siswa seperti yang telah disebutkan pada pembahasan sebelumnya. Keterbatasan lainnya mencakup pemilihan jumlah subjek dalam penelitian ini tidak melalui proses sampling meskipun sebisa mungkin dipilih sekolah-sekolah yang masing-masing termasuk dalam kategori rendah, sedang, dan tinggi.

\section{SIMPULAN}

Hasil penelitian ini menunjukkan adanya korelasi positif yang signifikan antara tingkat PCK guru matematika dengan prestasi belajar matematika siswa. Hasil ini juga diperkuat dengan hasil analisis yang menunjukkan bahwa kontribusi PCK guru matematika terhadap prestasi belajar matematika sebesar $16,1 \%$, sedangkan $83,9 \%$ sisanya dipengaruhi oleh faktor lain. Analisis awal terhadap data prestasi belajar dan PCK guru menunjukkan bahwa siswa di Kabupaten Manggarai masih memiliki prestasi belajar matematika yang rendah dan guru matematika SMP di Kabupaten Manggarai memiliki tingkat PCK yang rendah. Penelitian ini menunjukkan masih perlunya peningkatan kualitas guru terkhusus untuk aspek PCK guru. Oleh karena itu, perlu ada usaha nyata dan berkesinambungan, baik dari guru maupun instansi terkait, untuk meningkatkan kualitas guru khususnya penguasaan PCK. Usaha ini bukan hanya sebagai upaya untuk memperbaiki tingkat PCK guru, namun secara tidak langsung juga sebagai upaya untuk meningkatkan prestasi belajar siswa. Dalam usaha perbaikan terhadap hasil belajar siswa, perlu dipertimbangkan juga faktor-faktor lain yang terkait karakteristik individual siswa. Untuk memperdalam hasil penelitian, maka untuk lanjutan penelitian yang berlangsung perlu memastikan jumlah sampel yang representatif dengan populasi. Penelitian di masa yang akan datang dapat meneliti hubungan PCK dengan variabel lain seperti variabel-variabel yang terkait karakteristik afektif siswa. Sedangkan terkait prestasi belajar siswa, perlu juga diselidiki pengaruh dari faktor-faktor lain selain PCK yang telah dibahas pada penelitian ini. 
PYTHAGORAS: Jurnal Pendidikan Matematika, 15 (2), 2020 - 187 Maria Evarista Oktaviane Barut, Ariyadi Wijaya, Heri Retnawati

\section{DAFTAR PUSTAKA}

Absorin, A., \& Sugiman, S. (2018). Eksplorasi kemampuan penalaran dan representasi matematis siswa sekolah menengah pertama. Pythagoras: Jurnal Pendidikan Matematika, 13(2), 189-202.

https://doi.org/10.21831/pg.v13i2.21249

Alonzo, A. C., Kobarg, M., \& Seidel, T. (2012). Pedagogical content knowledge as reflected in teacher-student interactions: Analysis of two video cases. Journal of Research in Science Teaching, 49(10), 1211-1239. https://doi.org/10.1002/tea.21055

Aminah, N., \& Wahyuni, I. (2018). Design of capability measurement instruments pedagogic content knowledge (PCK) for prospective mathematics teachers. Journal of Physics: Conference Series, 1013(1), 1-5. https://doi.org/10.1088/1742-6596/1013/1/012112

Anthony, G., \& Walshaw, M. (2009). Characteristics of effective teaching of mathematics: A view from the West. Journal of Mathematics Education, 2(2), 147-164. http://educationforatoz.com/images/_9734_12_Glenda_Anthony.pdf

Appova, A., \& Taylor, C. E. (2019). Expert mathematics teacher educators' purposes and practices for providing prospective teachers with opportunities to develop pedagogical content knowledge in content courses. Journal of Mathematics Teacher Education, 22(2), 179-204. https://doi.org/10.1007/s10857-017-9385-z

Atay, D., Kaslioglu, O., \& Kurt, G. (2010). The pedagogical content knowledge development of prospective teachers through an experiential task. Procedia - Social and Behavioral Sciences, 2(2), 1421-1425. https://doi.org/10.1016/j.sbspro.2010.03.212

Badan Standar Pendidikan Nasional. (2018). Buku saku ujian nasional 2019. Kemdikbud. https://bsnp-indonesia.org/wpcontent/uploads/2019/03/19_02_19-Buku-Saku-UN-2019-revisi-BS-20-Feb-1.pdf

Ball, D. L., \& Bass, H. (2000). Interweaving content and pedagogy in teaching and learning to teach: Knowing and using mathematics. In J. Boaler (Ed.), Multiple perspectives on mathematics teaching and learning (pp. 83-104). Ablex.

Ball, D. L., Thames, M. H., \& Phelps, G. (2008). Content knowledge for teaching: What makes it special? Journal of Teacher Education, 59(5), 389-407. https://doi.org/10.1177/0022487108324554

Barut, M. E. O., \& Wijaya, A. (2020). Facilitating pedagogical content knowledge development through professional development intervention. Journal of Physics: Conference Series, 1581(1), 1-8. https://doi.org/10.1088/1742$6596 / 1581 / 1 / 012062$

Baumert, J., Kunter, M., Blum, W., Brunner, M., Voss, T., Jordan, A., Klusmann, U., Krauss, S., Neubrand, M., \& Tsai, Y. M. (2010). Teachers' mathematical knowledge, cognitive activation in the classroom, and student progress. American Educational Research Journal, 47(1), 133-180. https://doi.org/10.3102/0002831209345157

Brahier, D. J. (2016). Teaching secondary and middle school mathematics (5th ed.). Routledge.

Bucat, R. (2004). Pedagogical content knowledge as a way forward: Applied research in chemistry. Chemistry Education: Research and Practice, 5(3), 215-228. https://doi.org/10.1039/B4RP90025A

Campbell, P. F., Nishio, M., Smith, T. M., Clark, L. M., Conant, D. L., Rust, A. H., DePiper, J. N., Frank, T. J., Griffin, M. J., \& Choi, Y. (2014). The relationship between teachers' mathematical content and pedagogical knowledge, teachers' perceptions, and student achievement. Journal for Research in Mathematics Education, 45(4), 419459. https://doi.org/10.5951/jresematheduc.45.4.0419

Cohen, L., Manion, L., \& Morrison, K. (2007). Research methods in education (6th ed.). Routledge.

Dirgahayu, N. W. D. S. (2020). Pengaruh penguasaan Content Knowledge (CK) dan Pedagogical Content Knowledge (PCK) terhadap kinerja guru matematika SMP Negeri Kecamatan Kuta Selatan. [Master's thesis, Universitas Pendidikan Ganesha].

Ebel, R. L., \& Frisbie, D. A. (1991). Essentials of educational measurement (5th ed.). Prentice-Hall. 
Ekawati, R., Lin, F. L., \& Yang, K. L. (2015). Primary teachers' knowledge for teaching ratio and proportion in mathematics: The case of Indonesia. Eurasia Journal of Mathematics, Science and Technology Education, 11(3), 513-533. https://doi.org/10.12973/eurasia.2015.1354a

Evens, M., Elen, J., \& Depaepe, F. (2015). Developing pedagogical content knowledge: Lessons learned from intervention studies. Education Research International, 2015(1), 1-23. https://doi.org/10.1155/2015/790417

Gess-Newsome, J. (2015). A model of teacher professional knowledge and skill including PCK: Results of the thinking from the PCK Summit. In A. Berry, P. Friedrichsen, \& J. Loughran (Eds.), Re-examining Pedagogical Content Knowledge in Science Education (1st ed., pp. 28-42). Routledge.

Goos, M. (2013). Knowledge for teaching secondary school mathematics: What counts? International Journal of Mathematical Education in Science and Technology, 44(7), 972-983. https://doi.org/10.1080/0020739X.2013.826387

Gunur, B., Lanur, D. A., \& Raga, P. (2019). Hubungan kemampuan numerik dan kemampuan spasial terhadap kemampuan komunikasi matematis siswa. Pythagoras: Jurnal Pendidikan Matematika, 14(2), 224-232. https://doi.org/10.21831/pg.v14i2.27250

Hadi, S., Retnawati, H., Munadi, S., Apino, E., \& Wulandari, N. F. (2018). The difficulties of high school students in solving higher-order thinking skills problems. Problems of Education in the 21st Century, 76(4), 520-532. https://doi.org/10.33225/pec/18.76.520

Hair, J. F., Babin, B. J., Anderson, R. E., Black, W. C. (2018). Multivariate data analysis (8th ed.). Cengage.

Hakim, A. (2015). Contribution of competence teacher (pedagogical, personality, professional competence and social) on the performance of learning. The International Journal of Engineering and Science, 4(2), 1-12. http://www.theijes.com/papers/v4-i2/Version-3/A42301012.pdf

Hume, A., \& Berry, A. (2011). Constructing CoRes-A strategy for building PCK in pre-service science teacher education. Research in Science Education, 41(3), 341-355. https://doi.org/10.1007/s11165-010-9168-3

Kleickmann, T., Richter, D., Kunter, M., Elsner, J., Besser, M., Krauss, S., \& Baumert, J. (2013). Teachers' content knowledge and pedagogical content knowledge: The role of structural differences in teacher education. Journal of Teacher Education, 64(1), 90-106. https://doi.org/10.1177/0022487112460398

Lannin, J. K., Webb, M., Chval, K., Arbaugh, F., Hicks, S., Taylor, C., \& Bruton, R. (2013). The development of beginning mathematics teacher pedagogical content knowledge. Journal of Mathematics Teacher Education, 16(6), 403426. https://doi.org/10.1007/s10857-013-9244-5

Lee, D., \& Huh, Y. (2014). What TIMSS tells us about instructional practice in K-12 mathematics education. Contemporary Educational Technology, 5(4), 286-301. https://doi.org/10.30935/cedtech/6131

Lodico, M. G., Spaulding, D. T., \& Voegtle, K. H. (2010). Methods in educational research: From theory to practice (2nd ed.). Jossey-Bass.

Loughran, J., Milroy, P., Berry, A., Gunstone, R., \& Mulhall, P. (2001). Documenting science teachers' pedagogical content knowledge through PaP-eRs. Research in Science Education, 31(2), 289-307. https://doi.org/10.1023/A:1013124409567

Maryani, I., \& Martaningsih, S. T. (2015). Correlation between teacher's PCK (pedagogical content knowledge) and student's motivation in primary school. International Journal of Evaluation and Research in Education, 4(1), 38-44. http://doi.org/10.11591/ijere.v4i1.4490

Mullis, I. V. S., Martin, M. O., Foy, P., \& Arora, A. (2012). TIMSS 2011 international results in mathematics. TIMSS \& PIRLS International Study Center, Lynch School of Education, Boston College.

Mullis, I. V. S., Martin, M. O., Foy, P., \& Hooper, M. (2016). TIMSS 2015 international results in mathematics. TIMSS \& PIRLS International Study Center, Lynch School of Education, Boston College.

NCTM. (2000). Principle and standards for school mathematics. Author. 
$\mathrm{Ng}$, D. (2012). Using the MKT measures to reveal Indonesian teachers' mathematical knowledge: Challenges and potentials. ZDM - Mathematics Education, 44(3), 401-413. https://doi.org/10.1007/s11858-011-0375-9

Olfos, R., Goldrine, T., \& Estrella, S. (2014). Teachers' pedagogical content knowledge and its relation with students' understanding. Revista Brasileira de Educacao, 19(59), 913-944. https://doi.org/10.1590/S141324782014000900006

Pandey, B. D. (2017). A study of mathematical achievement of secondary school students. International Journal of Advanced Research, 5(12), 1951-1954. https://doi.org/10.21474/ijar01/6165

Park, S., \& Oliver, J. S. (2008). Revisiting the conceptualisation of pedagogical content knowledge (PCK): PCK as a conceptual tool to understand teachers as professionals. Research in Science Education, 38(3), 261-284. https://doi.org/10.1007/s11165-007-9049-6

Prasetyo, D. A. B., \& Rudhito, M. A. (2016). Analisis kemampuan dan kesulitan siswa SMP dalam menyelesaikan soal bilangan model TIMSS. Jurnal Pengajaran MIPA, 21(2), 122-128. https://doi.org/10.18269/jpmipa.v21i2.819

Rafi, I., \& Sugiman, S. (2019). Problem posing ability among prospective mathematics teachers. Pythagoras: Jurnal Pendidikan Matematika, 14(2), 188-198. https://doi.org/10.21831/pg.v14i2.29976

Retnawati, H., Djidu, H., Kartianom, K., Apino, E., \& Anazifa, R. D. (2018). Teachers' knowledge about higherorder thinking skills and its learning strategy. Problems of Education in the 21st Century, 76(2), 215-230. https://doi.org/10.33225/pec/18.76.215

Rosnawati, R. (2013). Kemampuan penalaran matematis siswa SMP Indonesia pada TIMSS 2011. Prosiding Seminar Nasional Penelitian, Pendidikan dan Penerapan MIPA, 1-6.

Sarkim, T. (2015). Pedagogical content knowledge: Sebuah konstruk untuk memahami kinerja guru di dalam pembelajaran. Prosiding Pertemuan IImiah HFI Jateng dan DIY XXIX, 7-12. http://repository.usd.ac.id/4429/

Shin, J., Lee, H., \& Kim, Y. (2009). Student and school factors affecting mathematics achievement: International comparisons between Korea, Japan and the USA. School Psychology International, 30(5), 520-537. https://doi.org/10.1177/0143034309107070

Shulman, L. (1987). Knowledge and teaching: Foundations of the new reform. Harvard Educational Review, 57(1), 1-23. https://doi.org/10.17763/haer.57.1.j463w79r56455411

Tanujaya, B., Prahmana, R. C. I., \& Mumu, J. (2017). Mathematics instruction, problems, challenges and opportunities: A case study in Manokwari Regency, Indonesia. World Transactions on Engineering and Technology Education, 15(3), 287-291. http://www.wiete.com.au/journals/WTE\&TE/Pages/Vol.15,\%20No.3\%20(2017)/16-Tanujaya-B.pdf

Telese, J. A. (2012). Middle school mathematics teacher's professional development and student achievement. Journal of Educational Research, 105(2), 102-111. https://doi.org/10.1080/00220671.2010.521209

Uysal, S. (2015). Factors affecting the mathematics achievement of Turkish students in PISA 2012. Educational Research and Reviews, 10(12), 1670-1678. https://doi.org/10.5897/err2014.2067

Wea, M. Y. (2012). Hubungan antara pengalaman pembelajaran, partisipasi dalam kegiatan MGMP, dan motivasi kerja dengan kompetensi profesional guru matematika SMP di Kabupaten Manggarai, Nusa Tenggara Timur. [Master's thesis, Universitas Negeri Yogyakarta].

Widodo, A. (2017). Teacher pedagogical content knowledge (PCK) and students' reasoning and wellbeing. Journal of Physics: Conference Series, 812(1), 1-7. https://doi.org/10.1088/1742-6596/812/1/012119

Wilson, S. M., Floden, R. E., \& Ferrini-Mundy, J. (2002). Teacher preparation research: An insider's view from the outside. Journal of Teacher Education, 53(3), 190-204. https://doi.org/10.1177/0022487102053003002 